\section{Regards sur l'économie allemande}

Bulletin économique du CIRAC

$92 \mid 2009$

\section{Varia}

\title{
Chine et UE
}

STUMBAUM May-Britt U., The European Union and China - DecisionMaking in EU Foreign and Security Policy towards the People's Republic of China

\section{(2) OpenEdition}

1 Journals

Édition électronique

URL : http://journals.openedition.org/rea/3776

DOI : 10.4000/rea.3776

ISBN : 978-2-8218-0880-5

ISSN : 1965-0787

Éditeur

CIRAC

Édition imprimée

Date de publication : 1 juillet 2009

ISSN : 1156-8992

Référence électronique

"Chine et UE », Regards sur l'économie allemande [En ligne], 92 I juillet 2009, mis en ligne le 28 août 2009, consulté le 22 septembre 2020. URL : http://journals.openedition.org/rea/3776 ; DOI : https:// doi.org/10.4000/rea.3776

Ce document a été généré automatiquement le 22 septembre 2020.

(c) CIRAC 


\section{Chine et UE}

STUMBAUM May-Britt U., The European Union and China - DecisionMaking in EU Foreign and Security Policy towards the People's Republic of China

\section{RÉFÉRENCE}

STUMBAUM May-Britt U., The European Union and China - Decision-Making in EU Foreign and Security Policy towards the People's Republic of China, DGAP-Schriften zur Internationalen Politik, Nomos, Baden-Baden, 2009, 250 p.

1 Qui, à l'échelle de l'Union européenne, décide de la stratégie à adopter envers la Chine, cette puissance globale émergente défiant les Européens au niveau économique, politique et idéologique? Et comment les lobbies, les médias, voire les Etats-Unis influencent-ils le jeu des relations sino-européennes? Rédigée par une chercheure associée à la Société allemande pour la politique étrangère (DGAP), la présente étude se propose d'y répondre, en revenant notamment sur deux conflits récents : l'embargo sur les armes de 2003-2005 et la crise du textile de 2005. Elle s'achève par des recommandations concrètes, destinées à inscrire sur le long terme des relations économiques et diplomatiques prospères entre l'UE et la République populaire de Chine. Via cet exemple, chercheurs et responsables économiques et politiques auront la possibilité de découvrir les processus décisionnels européens en matière de politique étrangère et de sécurité. (sh) 